IMEJ: Islamic Management and Empowerment Journal

Volume 2, Number 1, Juni 2020. p. 35 - 52

P-ISSN:2685-953X; e-ISSN:2686-0317

DOI: 10.18326/imej.v2i1.35-52

website: http://e-journal.iainsalatiga.ac.id/index.php/imej

\title{
Muda Berdaya: Sebuah Pendidikan Moderat Kritis Komunitas Santri Batang
}

\author{
Mochammad Najmul Afad \\ IAIN Pekalongan, Indonesia \\ m.najmul.afad@iainpekalongan.ac.id
}

\begin{abstract}
Radicalism is one of popular study. This condition is a form of response to the rise of violent behavior committed by a group in the name of religion. This study describes the youth empowerment model. The empowerment is done with critical moderate education that takes the locus of the Santri Batang community. Ethnographic methods were used in this study. The results of this study are the Santri Batang community emerged as a new empowerment movement in Batang District. Santri Batang becomes a community of young people who move in cyberspace and the real world. Visual content in the media produced and through direct encounters (Kopdar/kopi darat), the dogma of Islam are delivered with the style of young people able to spread the enthusiasm of studying Islamic studies Rahmatan Lil'alamin.
\end{abstract}

Keywords: Empowerment, Santri Batang, Moderation, Youth

\begin{abstract}
Abstrak
Radikalisme merupakan salah satu kajian yang populer. Kondisi ini sebagai wujud respon atas maraknya perilaku kekerasan yang dilakukan atas nama agama. Penelitian ini menjelaskan mengenai model pemberdayaan anak muda. Pemberdayaan dilakukan dengan pendidikan moderat kritis yang mengambil locus komunitas Santri Batang. Metode etnografi digunakan dalam penelitian ini. Hasil dari penelitian ini adalah komunitas Santri Batang muncul sebagai sebuah gerakan pemberdayaan baru di Kabupaten Batang. Santri Batang menjadi komunitas anak muda yang bergerak di dunia maya dan dunia nyata. Content visual di media yang diproduksi dan melalui perjumpaan langsung (kopdar/kopi darat), ajaran Islam disampaikan dengan gaya anak muda mampu menyebarkan semangat belajar kajian Islam Rahmatan Lil'alamin.
\end{abstract}

Kata Kunci: Pemberdayaan, Santri Batang, Moderasi, Pemuda 


\section{Pendahuluan}

Kajian tentang radikalisme kian popular dalam dekade ini. Kondisi ini sebagai wujud respon atas maraknya perilaku kekerasan yang dilakukan sekelompok atas nama agama. Dalam sebuah paparan materi Kementrian Pertahanan RI tahun 2016, yang penulis ambil dari bahan presentasi Dr. Miftahuddin, M.Ag berjudul Moderasi Beragama dalam Kehidupan Multikultural yang disampaikan dalam diskusi ilmiah di UIN Walisongo pada 23 November 2019 memaparkan permasalahan bangsa hari ini ialah Indonesia rentan dipecah belah dengan berbagai isu yang dimainkan oleh sekelompok orang. Beberapa isu yang dimainkan ialah china, komunis, PKI, pemerintah kafir, syiah, kristenisasi/islamisasi, rebut kekuasaan, revolusi untuk khilafah.

Berbagai problem di atas kian berpolemik tatkala narasi-narasi ini belum direspon secara sistematis dan tuntas. Dalam seminar disebutkan bahwa ketika narasi-narasi radikal tersebut tidak segera diselesaikan, maka aksi seperti 411 akan terus berulang, dengan wajah yang sama atau berbeda. Di lain sisi, kasus-kasus intoleransi masih banyak yang belum terselesaikan dan masih berlanjut seperti Ahmadiyah Transito, HKBP Filadelfia, GKI Yasmin, Ahmadiyah Kuningan, Syi'ah Sampang Madura, dan kasus lainnya. Ini berarti perlu upaya penanganan permalahan tersebut secara tegas, terpadu, menyeluruh dan strategis dalam penanganan terorisme. Meski materi ini disampaikan pada 2016 oleh kemenhan kemudian diulas kembali di pada November 2019 terlihat rentetan permasalahan radikalisme tetap menjadi nomor satu untuk segera diselesaikan.

Menengok beberapa kasus radikalisme dilakukan oleh pemuda. Kasus bom Hotel JW Marriott dan Hotel Ritz-Carlton, Kuningan, Jakarta Selatan pada 17 Juli lalu bernama Dani Dwi Permana merupakan remaja berusia 18 tahun yang merupakan lulusan dari sebuah SMA swasta di Jakarta (Kompas.com, 2009). Bom Bali 2 tahun 2005 juga sama, usia pelakunya kisaran 20-25 tahun (Detik.com, 2015). Pelaku Bom Gereja Santa Maria Surabaya 2018 ialah Dita Oepriarto cukup populer di kalangan Rohis SMAN 5 Surabaya, karena menjabat sebagai ketua Rohis semasa SMA(Kumparannews, 2018). Terakhir pelaku bom di Solo pada awal Januari 2019 berusia 22 tahun 
(Tribunnews.com, 2019).

Aksi-aksi teror terlah membawa dampak sosial, psikis dan budaya. Dampak yang pertama kali yang muncul adalah terancamnya keamanan dan stabilitas sosial. Data dari tahun 2008-2017 menunjukkan bahwa telah terjadi peningkatan kematian yang diakibatkan dari aksi teror. Bahkan jumlahnya mencapai ribuan setiap tahun. Pada tahun 2014 jumlah korban jiwa mencapai 32.763 (katadata.com, 2019).

Grafik 1. Data korban jiwa dari aksi teror di dunia

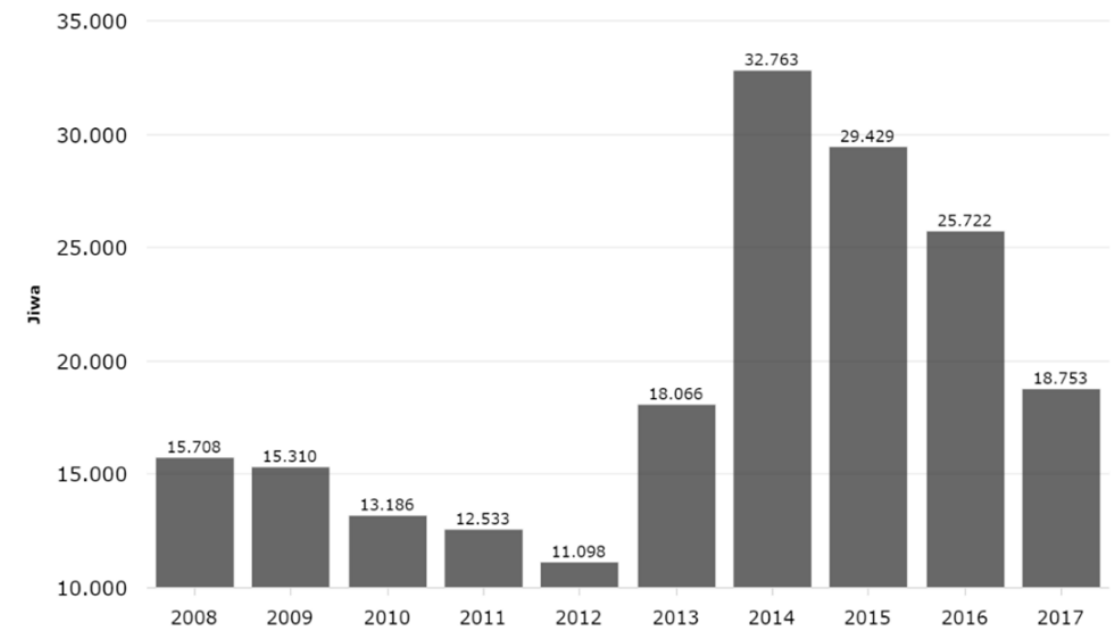

Dkatadata

Trdataboks

Sumber: katadata.co.id (diakses 06 Juli 2020)

Dalam kelompok teroris terdapat pemuda dengan jumlah yang tidak sedikit, terlihat dari data dan realitas berita di atas. Merujuk pada Undang-Undang Nomor 40 tahun 2009 menyebut pemuda adalah warga negara Indonesia yang memasuki periode penting pertumbuhan dan perkembangan yang berusia 16 (enam belas) sampai 30 (tiga puluh) tahun. Undang-Undang kepemudaan menyebut pembangunan kepemudaan adalah proses memfasilitasi segala hal yang berkaitan dengan kepemudaan. Pelayanan kepemudaan adalah penyadaran, pemberdayaan, dan pengembangan kepemimpinan, kewirausahaan, serta kepeloporan pemuda. Serta pemberdayaan 
pemuda adalah kegiatan membangkitkan potensi dan peran aktif pemuda. Artinya secara yuridis anak muda atau pemuda mempunyai peran baik sebagai sebagai subyek amupun obyek dari pembangunan itu sendiri.

Dalam konsep dasar pemberdayaan diartikan sebagai proses pembangunan dengan memasukkan nilai sosial dalam membangun paradigma baru dalam pembangunan (Noor, 2011). Konsep pemberdayaan masyarakat sebenarnya berangkat dari menempatkan manusia sebagai subjek pembangunan dan perubahan. Dalam pengertian ini dibutuhkan power dan adanya keberpihakan(Zubaedi, 2016).

Masalah sosial tentang pemuda akan lebih dapat dikelola melalui berbagai hal. Pemuda dengan realitas bahwa masih dalam proses pencarian jati diri, membutuhkan sebuah wadah, komunitas, kelompok atau semacamnya. Wadah tersebut bertujuan dapat merepresentasikan profile diri. Salah satu yang dapat dilakukan oleh wadah tersebut adalah pemberdayaan pemuda seperti konsep dari Undang-Undang.

Melanjutkan konsep pemberdayaan pemuda menurut UU Nomor 40 tahun 2009 tentang pemuda, konsep pemberdayaan harus dilakukan. Mereka harus dilepaskan dan dibebaskan dari apapun yang mengikat termasuk ikatan sosial. Pemberdayaan pada pemuda perlu merujuk pada nilai pancasila. Dalam hal ini Pancasila selaras dengan karakteristik pemuda yang berfikir merdeka (sila-4) dan egaliter (sila5) (Wulandari et al., 2017). Wadah atau komunitas tersebut telah terbentuk di Kabupaten Batang dengan nama Santri Batang.

Santri Batang merupakan sebuah komunitas yang memiliki tujuan untuk mewadahi pemuda Batang dengan memberikan pendidikat moderat kritis. Jumlah pemuda di Kabupaten Batang, Provinsi Jawa Tengah dapat dilihat dari data Badan Pusat Statistik sebagai berikut(Statistik, 2018): 
Tabel 1. Jumlah Penduduk Menurut Usia dan Jenis Kelamin

\begin{tabular}{|c|c|c|c|}
\hline \multirow{4}{*}{$\begin{array}{c}\text { Kelompok } \\
\text { Umur/Kohort }\end{array}$} & \multicolumn{3}{|c|}{$\begin{array}{l}\text { Jumlah Penduduk Menurut Kelompok Umur dan } \\
\text { Jenis Kelamin (Jiwa) }\end{array}$} \\
\hline & Laki-laki & Perempuan & Jumlah \\
\hline & 2018 & 2018 & 2018 \\
\hline & Tahun & Tahun & Tahun \\
\hline $0-4$ & 30316 & 28750 & 59066 \\
\hline 05-Sep & 31038 & 29929 & 60967 \\
\hline Okt-14 & 32128 & 30806 & 62934 \\
\hline $15-19$ & 33727 & 31907 & 65634 \\
\hline $20-24$ & 34993 & 32535 & 67528 \\
\hline $25-29$ & 29280 & 28389 & 57669 \\
\hline 30-34 & 25484 & 26119 & 51603 \\
\hline 35-39 & 26156 & 27288 & 53444 \\
\hline $40-44$ & 26828 & 27767 & 54595 \\
\hline $45-49$ & 26576 & 26601 & 53177 \\
\hline 50-54 & 22871 & 24353 & 47224 \\
\hline 55-59 & 20757 & 21359 & 42116 \\
\hline $60-64$ & 16144 & 16556 & 32700 \\
\hline $65-69$ & 11111 & 11677 & 22788 \\
\hline 70+ & 13165 & 17767 & 30932 \\
\hline Jumlah & 380574 & 381803 & 762377 \\
\hline
\end{tabular}

Sumber: BPS Kabupaten Batang tahun 2018

Berdasarkan dari UU No 40 tahun 2009 maka pada data tersebut, jumlah pemuda di Kabupaten Batang 190.831 orang yang jika dibandingkan dengan jumlah total penduduk mencapai 25\%. Sehingga dengan potensi tersebut, komunitas Santri Batang memiliki peluang untuk mewadahi pemuda tersebut, tentunya mereka yang muslim. Sejak tahun 2017, komunitas ini dapat memiliki anggota sekitar 250 orang. Pesan yang disampaikan dilakukan dari social media dan pertemuan langsung. Komunitas Santri Batang melakukan beberapa kegiatan yang akan mengarahkan pemuda ke dalam sebuah konsep pendidikan moderat kritis dengan semangat pemberdayaan. 
Kegiatan pemberdayaan pemuda merupakan aktivitas yang secara akademis dapat dilihat secara analisa sosial budaya. Atas dasar tersebut kemudian penulis mengambil studi tentang pemberdayaan anak muda sebuah pendidikan moderat kritis komunitas Santri Batang. Tulisan ini berusaha menjelaskan model pemberdayaan anak muda sebagai sebuah pendidikaan moderasi beragama yang mengambil studi kelompok komunitas anak muda Santri Batang.

\section{Metode Penelitian}

Penelitian ini menggunakan metode etnografi. Etnografi Etnografi online atau yang kerap disebut sebagai netnografi dan etnografi offline juga dipakai sebagai pendekatan dalam penelitian. Dengan memanfaatkan grup whatsapp dan media sosial instragram Santri Batang peneliti mendapatkan data. Teknik wawancara dan observasi partipatoris digunakan dalam penelitian ini. Penulis mengikuti setiap kegiatan Santri Batang baik dalam dunia maya maupun dunia nyata. Hal yang menjadi ciri khas dalam penelitian ini ialah penulis merupakan salah satu anggota dan penggerak aktif dalam komunitas Santri Batang. Pendekatan ini yang disebut sebagai self etnografi ini mempunyai kekurangan, yakni peneliti boleh jadi tidak sepenuhnya membuat catatan lapangan dengan detail. Sebab peneliti kadang menganggap aktivitas keseharian merupakan hal biasa dan kurang menarik.

\section{Hasil dan Pembahasan}

\section{Sekilas tentang Komunitas Santri Batang}

Sejarah berdirinya komunitas Santri Batang, tidak bisa lepas dari hubungan antara sosok guru atau Kyai/ Habaib dan murid. Tahun 2016 awal, Kota Pekalongan menjadi tuan rumah diselenggarakannya Konferensi Bela Negara. Dalam pertemuan itu hadir Ulama seIndonesia dan perwakilan dari beberapa negara, TNI, Polri. Acara tersebut mencetuskan salah satunya Indonesia sebagai inisator Bela Negara (Republika, 2016). Atas dasar pertemuan itu pula, disebutkan bahwa media sangat berperan besar dalam mensyiarkan Bela Negara. Sebuah ajaran untuk menjaga negara dari segala ancaman dan fitnah yang kelak memecah bangsa. 
Seiring berjalannya waktu, muncul masalah yang semakin mendesak yaitu degradasi moral, munculnya hoax, dan ajaran serta ujaran kebencian terhadap suatu kaum. Masalah ini tentu menjadi sebuah hal yang perlu dipikirkan bersama. Apalagi anak muda, yang kelak menjadi penerus bangsa. Hadirnya Santri Batang merupakan ide dari buah pikir guru-guru yang diterjemahkan para santri untuk gemar belajar dan mensyiarkan ajaran Islam.

Berdasarkan latar belakang tersebut, dua anak pemuda Batang bernama Jauhari Umar dan Najmul Afad berjumpa, mereka berdiskusi mengenai permasalahan sosial, keagamaan dan media pada bulan Agustus 2017. Selanjutnya keduanya berdiskusi dengan tokoh-tokoh muda Batang yang ternyata juga berfikiran sama namun belum terwadahi secara maksimal. Hal ini menunjukkan bahwa problem serta potensi ini memang lahir dan menjadi tanggung jawab bersama bukan segelentir orang saja. Sehingga kemudian terbentuklah komunitas yang diberinama Komunitas Santri Batang.

Sejak awal berdirinya, anggota komunitas Santri Batang berusia 14-26 tahun. Mereka merupakan para santri atau anak muda yang berasal dari atau tinggal di Kabupaten Batang. Anggota Santri Batang diantaranya pernah dan sedang mengenyam sebagai santri di pondok pesantren yang tersebar di Indonesia. Beberapa lainnya merupakan santri kalong, sebutan ditujukan kepada mereka yang hanya mengaji tanpa bermukim. Mereka gemar mengikuti pengajian baik di musholla/masjid, pondok pesantren, majlis taklim serta melalui media sosial seperti youtube, instagram, twitter dan facebook. Atas dasar itu pula kemudian beberapa mempertanyakan dimana letak pesantren dari komunitas Santri Batang. "Jarene Santri Batang, tapi ora genah pondoke ning ndi (katanya Santri Batang, tapi tidak jelas pesantrennya dimana)", cibiran ini ditujukan kepada beberapa anggota Santri Batang yang tidak pernah mengenyam pondok pesantren. Menanggapi cibiran atas pertanyaan tersebut founder (pendiri) Santri Batang Jauhari Umar justru mengajak memahami defiisi santri. KH. Mustofa Bisri (Gus Mus) pengasuh Pondok Pesantren Raudlatut Thalibin, Leteh, Rembang dan menjadi Rais Syuriah PBNU "Santri bukan yang mondok saja, tapi siapapun yang berakhlak seperti santri, adalah Santri" (Seniman NU, 2019). 
Proses perkembangan Komunitas Santri Batang tidak lepas dari peran para intelektual muda asal Batang. Jauhari Umar adalah pendiri Santri Batang yang telah menyelasikan studi Sarjananya di Ezzitouna Univetsity, Tunisia dan menjadi lulusan terbaik. Tokoh intelektual ini memberi warna dalam komunitas Santri Batang. Jauhari banyak mengeluarkan inovasi dalam berkegiatan Santri Batang serta menggunakan jaringannya untuk mengembangkan Komunitas Santri Batang. Jauhari membawa pesan "keotentikan ajaran Islam" karena dianggap sosok santri yang telah belajar di wilayah negara Islam (baca: Timur Tengah). Gelar "Lc" yang disandang Jauhari Umar membuat dirinya banyak disambangi masyarakat. Kondisi inilah yang menjadikan Komunitas Santri Batang semakin dikenal dan kontributif. Alasan inilah yang kemudian menjadikan Santri Batang menjadi rujukan anak muda untuk belajar Islam dengan sesamanya.

\section{Anak Muda, Media dan Narasi Islam Ramah}

Kategori anak muda menurut White dan Nafs adalah youth as generation, youth as transition dan youth as makers and consumers of culture. Sebagai generasi, anak muda merupakan aktor yang berperan dalam perubahan ekonomi dan sosial. Anak muda sebagai transisi mengandung makna proses kehidupan manusia dari fase anak muda menjadi dewasa. Sementara sebagai pencipta dan konsumen dari budaya, anak muda turut serta menciptakan dan menjadi penikmat dari budaya(Naafs \& White, 2012).

Definisi anak muda sebagai youth of transision menjadikan anak muda wajib belajar dan melakukan hal-hal yang sesuai norma. Anak muda yang belum tahu apa-apa, perlu dibimbing. Maka kalangan tua berusaha menyampaikan nilai-nilai, dan ajarannya kepada anak muda agar anak muda mematuhi norma, dan menjadi manusia yang sesuai dengan harapan masyarakat (Naafs \& White, 2012). Kondisi ini menjadikan anak muda berusaha mempelajari tentang ajaran Islam. Masyarakat membangun institusi pendidikan khusus yang mengajarkan ajaran Islam dan mudah ditemui, diantaranya berbentuk pondok pesantren, majlis ta'lim, masjid, langgar atau musholla, Taman Pendidikan Al-qur'an (TPQ), dan sekolah.

Selain dari institusi tersebut, terdapat juga anak muda yang 
mengonsumsi buku-buku yang mengajarkan Islam, dan mengikuti cermah-cermah melalui media massa secara online. Keterbatasan anak muda untuk membaca kitab kuning menjadi titik tolak anak muda gemar membaca buku-buku Islami. Mereka tertarik oleh juduljudul buku yang terkesan religious dan bisa memenuhi kebutuhan ketidaktahuan tentang tata cara beribadah. Rasa malu untuk belajar agama karena usia yang sudah dewasa menjadi sebab anak muda untuk tidak belajar langsung kepada guru. Selain itu, keterbatasan ruang dan waktu juga menjadi alasan buku dan media sosial menjadi rujukan utama sebagai sarana belajar ke-Islaman. Kondisi ini juga disuburkan oleh semangat ingin mencari tahu (curiosity) mengenai hal-hal baru. Semua materi agama bisa masuk ke telinga anak muda, tanpa tedeng aling-aling (penyaring). Hal-hal yang dianggap baru, mempunyai penjelasan rasional dan bisa diterima diterima oleh akal menjadi pegangan sekaligus dasar anak muda dalam beribadah.

Komunitas Santri Batang bukan kumpulan Gus atau Ning (putra dan putri dari Kyai) di Kabupaten Batang. Komunitas ini berusaha menampung anak muda yang tidak hanya mengenyam pondok pesantren saja, melainkan juga anak muda yang mau dan gemar mengaji. Keadaan ini yang menjadi ciri khas keanggotaan komunitas Santri Batang.

Jauhari Umar sebagai pendiri dari komunitas Santri Batang menegaskan bahwa kajian offline harus diagendakan secara rutin. Forum tersebut menjadi sarana regenerasi komunitas Santri Batang. Hal demikian ini dilakukan untuk membangun sikap terbuka anak muda. Sebab fenomena beragama yang eksklusif masih ditemui di kalangan anak muda. Sikap eksklusif tersebut menjurus kepada anggapan kelompoknya saja yang paling benar sehingga rentan sekali terhadap tindakan dan gerakan radikal. Meskipun anak muda sudah terdidik, yang mengenyam pendidikan tinggi namun anak muda harus terus dibekali ilmu-ilmu agama. Ajaran tersebut diambil dari kitabkitab para ulama terdahulu yang mengajarkan toleransi, Islam rahmatan lil alamin dan moderasi beragama. Rutinitas kajian offline ini sekaligus menjawab tantangan zaman munculnya kelompokkelompok radikal yang secara secara pendidikan sudah well educated (berpendidikan tinggi) yang seharusnya berfikir terbuka, menerima 
masukan, bersikap toleransi justru sebaliknya bersikap eksklusif.

Dalam hal ini media sosial dijadikan sebagai media propaganda sekaligus perekrutan anggota baru pada kelompok radikal (Muthohirin, 2015). Salah satunya adalah lewat facebook, yaitu pada halaman facebook digunakan untuk to promote hate and conflated those principles of free speech with religious and racial hatred of communities, simply because of the way they dress and what they practice (Awan, 2016). Dalam studi lain tentang Felix Siauw, salah satu pemimpin agama Hizbut Tahrir Indonesia menggunakan startegi online dan offline, pendekatan visual dan tekstual, serta ambisi politik dan metode artistic. Strategi yang dilakukan Felix Siauw ini mampu mengundang dan meyakinkan pengikut potensial yakni kalangan muda untuk percaya dan menjunjung tinggi ideologi HTI. Pesan visual dan persuasi Islamis, seperti yang dipraktikkan Felix Siauw yang disebutnya sebagai menyenangkan namun radikal, penuh warna namun konservatif, sederhana namun keras, interaktif namun dogmatis (Weng Hew, 2018).

Dalam melakukan pengelolaan media sosial sebagai alat penyampaian dakwah, maka standar literasi media Islam daring sebaiknya memenuhi tujuh standar diantaranya prinsip produksi berita online, etika distribusi berita, jaminan akurasi dan komitmen antihoaks, spirit amar maruf nahi munkar, asas hikmah dalam dakwah, prinsip dalam interaksi digital, dan prinsip kemerdekaan pers (Setyaningsih, 2019). Sejalan dengan konsep ini lah maka Komunitas Santri Batang juga memanfaatkan media sosial sebagai alat untuk menyampaikan pesan dakwah. Data 18 Mei 2020, media sosial instagram Santri Batang (@santribatang) tercatat mempunyai follower sebanyak 2.556 dengan 2.161 postingan dan 809 pengikut. Melalui instagram ini, Santri Batang memproduksi dan menyebarkan pesan melalui konten visual sebagai bentuk narasi kontra radikalisme.

Pesan visual yang diproduksi oleh tim media Santri Batang disebarluaskan melalui intagram, facebook, website dan grup whatsapp komunitas Santri Batang yang berjumlah 250 peserta. Setiap anggota komunitas memiliki grup whatsapp lain dan akun social media, jadi setiap anggota bisa membagikan lewat beberapa media tersebut. Penulis turut memposting pesan visual dari Santri 
Batang melalui whatsapp yang dalam satu hari dilihat minimal oleh 300 orang. Angka ini cukup besar, apalagi jika dihitung secara detail semua anggota dengan beberapa viewer (orang yang melihat pesan visual tersebut). Boleh jadi dalam satu pesan visual tersebut telah dilihat oleh 2.000 orang tiap harinya.

Dalam konsep dakwah atau pesan agama, terdapat definisi baru tentang terminologi ulama sebagai religius leader berhimpitan dengan terminologi opinion maker dan opinion leader sebagai istilah baru pada era media baru. Temuan ini didasarkan pada wacana tentang penolakan Islam Nusantara di Sumatera Barat lebih aktif dibahas sebagai topik pembicaraan netizen facebook. Meski sebetulnya pada kalangan masyarakat perbincangan mengenai Islam Nusantara ini sudah selesai dengan mendudukkan tradisi Sumatera Barat dengan ajaran Islam itu sendiri sebagai dua hal yang tidak bisa dilepaskan atau dalam istilah Adaik Bersandi Syarak, Syarak Bersandi Kitabullah dan Syara' Mangato, Adat Mamakai (Ridwan et al., 2019). Dengan demikian Santri Batang melalui media sosial menjadi sarana untuk mengajak, mempengaruhi dan membentuk opini publik tentang Komunitas Islam anak muda yang menyampaikan pesan Islam ramah. Santri Batang sebagai komuitas anak muda bukan hanya sebatas sebagai pemimpin agama yang dalam hal ini ialah ketua Santri Batang yakni Jauhari Umar, Lc tetapi juga menjadi pembuat opini tentang Islam ramah.

\section{Model Pemberdayaan Anak Muda: Sebuah Pendidikan Moderat Kritis Komunitas Santri Batang}

Asosiasi Penyelenggara Jasa Internet Indonesia tahun 2018 menyebut bahwa 171,17 juta orang mengakses internet atau $64,8 \%$ penduduk Indonesia telah mengakses internet dari total jumlah penduduk 264,16 juta. Data ini perlu dibaca kembali khususnya kalangan muda. Mereka hampa sehari tanpa memegang smartphone. Alvara Indonesia Gen Z and Millinial Report 2020: The Battle of Our Generation (2020) membagi empat kalangan masyarakat yang mengakses internet. Baby Boomer mereka lahir tahun 1944-1964), Generasi X, lahir tahun 1965-1980, Generasi Millennial lahir tahun 1981-1997 dan Gen Z lahir usia 1998-2010. Alvara mengatakan Generasi X yang disebutnya sebagai digital immigration mengonsumsi 
internet 63,2 \%. Kaum Gen X tergolong medium user dengan mengonsumsi internet 1-3 jam per hari. Sementara generasi Millenial atau disebut sebagai internet generation menggunakan internet sebesar 88,4\%. Mereka terkategori sebagai heavy user dengan 4-6 jam per hari mengakses internet. Gen $\mathrm{Z}$ atau mobile generation menggunakan internet sebesar 93,9\% dan tergolong addicted user. Mereka mengonsumsi internet lebih dari 7 jam per hari. Menurut Survei Sosial Ekonomi Nasional (Susenas) BPS jumlah Generasi Pasca Millennial atau Gen Z sebesar 29,23\%, generasi milenial (gen Y) sebesar 33,75\%, generasi $X$ sebesar 25,74 sementara generasi baby boom + veteran (tua) 11,27 (Alvara Research Center, 2020).

Arus informasi pun sangat kuat, karena dengan mudah masuk melalui pintu-pintu setiap diri anak muda. Hal ini menjadi peluang yang cukup besar untuk mensyiarkan pesan damai dan menentramkan. Mereka yang ikut dalam komunitas Santri Batang merasa bahwa kebutuhan pengembangan potensi dan keterampilannya tersalurkan. Dalam memperlebar jaringan, Santri Batang senafas dengan Arus Informasi Santri (AIS) Jawa Tengah dan AIS Nusantara sebagai pusatnya. Hal yang sama juga berarti bahwa lahirnya Santri Batang merupakan pancaran atas semangat yang digelontarkan oleh Arus Informasi Santri Nusantara, sebuah perkumpulan para santri yang berdakwah melalui media.

Sebuah kegiatan bertajuk Kopdar Aja (Kajian Pelajar dan Remaja Ahlussunah Waljamaah) digelar dalam rangka mewadahi para kaum muda. Kopdar pertama dilaksanakan dengan membahas kitab Hujjatu Ahlissunnah Wal Jamaah (dalil-dalil amaliyah aswaja). Kegiatan ini digelar 17-31 Desember 2013 di Musholla Baitul Muttaqin pada hari liburan sekolah. Materi disampaikan dengan power point presentation dengan memanfaatkan tekonologi komputer. Selain mengaji, peserta Kopdar Aja juga belajar tentang beasiswa Turkey yang disampaikan oleh anggota Santri Batang alumni Turkey.

Kopdar Aja melebar, tidak hanya dilaksanakan di musholla saja, tetapi bergeser di ruang publik yakni Jalan Veteran. Lokasi yang penuh dengan keramaian, tepat berada di sebelah selatan alun-alun Kabupaten Batang. Acara ini bekerja sama dengan komunitas anak muda, Lemah Abang (Lesehan Mahasiswa Pekalongan Batang). 
Kegiatan ini dilaksanakan pada bulan Ramadhan 1440 hijriah. Ngaji on the Street dan Bagi Takjil menjadi tajuk kegiatan ini. Acara dimulai dengan mengaji sembari menanti waktu buka puasa. Selanjutnya dilaksanakan bagi takjil dan buka puasa bersama.

Gen Z dan Younger Millennial mempunyai kebiasaan membicarakan hal-hal seputar musik, teknologi, pendidikan, olahraga dan film. Jauh berbeda dengan Older Millennial dan Gen X kaum yang lebih tua cenderung banyak membahas tema-tema serius, seperti sosial politik, ekonomi, budaya, dan agama (Alvara Research Center, 2020). Berpijak dari hal ini, perbincangan hingga kegiatan Komunitas Santri Batang tidak jauh-jauh dari hal yang sama dengan apa yang dibahas alvara yakni seputar pendidikan.

Kegiatan Santri Batang juga dapat dipahami sebagai proses pengembangan dan pemberdayaan pemuda. Merujuk pada padangan Christenson dan Robinson dalam istilah community development sebagai suatu proses yang dilakukan oleh komunitas masyarakat tertentu dalam mengembangkan prakarsa untuk melakukan tindakan sosial baik melalui ataupun tanpa intervensi dalam rangka mengubah situasi ekonomi, sosial, kultural dan atau lingkungan mereka (Soetomo, 2006). Pandangan ini menekankan pentingnya prakarsa dan partisipasi masyarakat bukan intervensi oleh suatu pihak tertentu.

Komunitas Santri Batang lahir dan besar karena proses kegelisahan bersama kemudian lahir gerakan bersama. Komunitas anak muda ini tentu layak disebut bahwa dalam komunitas ini telah terwujud community development dalam rangka tujuan tertentu yaitu menyelesaikan masalah degradasi moral, munculnya hoax, dan ajaran serta ujaran kebencian terhadap suatu kaum yang dapat memecah stabilitas keamanan dan ketentraman bangsa. Dalam istilah lain gerakan komunitas Santri Batang ini sebagai gerakan moderasi beragama.

Kementrian Agama Repubik Indonesia dalam bukunya Moderasi Beragama menyebut moderasi berasal dari bahasa latin moderâtio, yang mengandung arti ke-sedang-an (tidak kelebihan dan tidak kekurangan). Moderasi tersebut juga mempunyai makna penguasaan diri (dari sikap sangat kelebihan dan kekurangan). Jika berpijak dari 
pandangan ini, maka moderasi merupakan pandangan yang bukan ekstrimis, tidak memihak pada salah satu sudut melainkan tepat berada di tengah atau imbang (Kementrian Agama, 2019).

Lebih lanjut dalam buku tersebut dijelaskan bahwa bagian prinsip dasar dalam moderasi beragama adalah "selalu menjaga keseimbangan di antara dua hal, misalnya keseimbangan antara akal dan wahyu, antara jasmani dan rohani, antara hak dan kewajiban, antara kepentingan individual dan kemaslahatan komunal, antara keharusan dan kesukarelaan, antara teks agama dan ijtihad tokoh agama, antara gagasan ideal dan kenyataan, serta keseimbangan antara masa lalu dan masa depan" (Kementrian Agama, 2019).

Santri Batang mengajarkan tentang keseimbangan. Melalui kajian-kajian, kopi darat mereka berkumpul dalam rangka meningkatkan literasi. Salah satu pemikiran yang mereka pegang dari Makmun Rasyid, yakni cara memberantas hoax, yakni dengan meningkatkan literasi. Literasi ini menjadikan anggota Santri Batang mempunyai banyak wacana dan pandangan atas suatu hal, sehingga tidak mudah termakan hoax. Sikap mencari tahu, dan gemar berdiskusi menjadi wadah untuk angota santri Batang untuk bertabayun atas sebuah berita dan mengklarifikasinya sehingga tidak mudah menyalahkan pada salah satu pihak. Sikap inilah yang sejalan dengan prinsip moderasi beragama yang tidak mudah menyalahkan, bukan ekstrimis melainkan selalu mengutamakan pemikiran jernih dan di tengah-tengah.

Kegiatan bertajuk Sedekah Puisi dengan tema besar "Moderasi Beragama dengan Mensyukuri Keberagaman" diselenggarakan oleh Santri Batang pada awal tahun 2020. Beberapa tema turunannya ialah "Moderasi Islam, Islam Ramah, Islam Rahmatan Lil Alamin dan Mensyukuri Keberagaman". Kegiatan ini menampung potensi anggota Santri Batang dalam bidang sastra. Kegiatan ini sekaligus menjawab banyaknya strategi untuk menyampaikan pesan damai moderasi beragama dengan cara anak muda.

Anak muda diberi kebebasan sesuai keinginannya. Hal yang khas dari komunitas Santri Batang ialah anggotanya tidak harus setiap hari berkegiatan. Santri Batang menyadari bahwa memang penting terus bergerak tapi juga mengerti atas kondisi anak muda yang harus 
belajar, bekerja dan mengembangkan passion lainnya. Kondisi inilah yang menjadikan anggota Santri Batang betah dan tetap bisa menjalankan tugasnya sebagai individu sebagai anak, pekerja dan juga pelajar serta santri. Sejalan dengan Afad menyebut beberapa ciri gerakan anak muda ialah anak muda mudah bosan, menyukai hal-hal yang menyenangkan (Afad, 2018).

Conyers menekankan defisini komunitas sebagai hal yang utama dalam proses community development ini. Pertama, konsep komunitas mengandung unsur fisik, yang menggambaran adanya kelompok manusia yang hidup di daerah tertentu dan saling berinteraksi satu sama lain. Kedua, anggota komunitas memiliki ciri khas yang sama yang menyebabkan timbulnya identifikasi mereka sebagai sebuah kelompok. Ketiga, suatu komunitas mempunyai keserasian dasar dalam perhatian dan aspirasi (Soetomo, 2006).

Davies mempertegas unsur-unsur dalam komunitas berupa lokalitas, hubungan emosional, keterlibatan sosial, kohesi sosial dan kepentingan bersama. Selanjutnya komponen-komponen tersebut menjadi pendorong tumbuhnya jaringan sosial dalam komunitas yang dibangun baik melalui interaksi dan relasi sosial yang bersifat formal dan informal. Jaringan sosial tersebut dapat mendorong tindakan individual maupun tindakan kolektif dalam menghadapi berbagai persoalan (Soetomo, 2006).

UNESCO (United Nations, Educational, Scientific and Cultural Organization) mencanangkan empat pilar pendidikan yakni: (1) learning to know, (2) learning to do (3) learning to be, dan (4) learning to live together. Berpijak dari pandangan tersebut, Santri Batang sebagai komunitas anak muda menyuguhkan pembelajaran (learning to know) tentang kajian keIslaman. Melalui forum-forum Santri Batang seperti Kopdar Aja dan juga media kampanye melalui media sosial disampaikan tentang pemngetahuan Islam. Selanjutnya komunitas ini mengajarkan untuk melakukan sesuatu (learning to do) yang berkaitan dengan ke-Islaman, yang berupa moderasi beragama. Bukan sebatas mempelajari muatan agama Islam, melainkan juga praktik amaliyah harian sebagai umat muslim dipelajari dan dilakukan oleh anggota Santri Batang. 
Learning to be teraplikasi dalam bentuk proses menjadi anak muda yang moderat dan berkontribusi untuk masyarakat. Sementara learning to live together mengajak anggota komunitas Santri Batang untuk hidup bersama dengan sesama anak muda dan juga masyarakat. Empat pilar yang dicanangkan UNESCO menjadi sebuah keseluruhan rangkaian proses pendidikan dalam Komunitas Santri Batang.

Pendidikan moderat kritis dibangun dan terbangun dalam komunitas Santri Batang menjadi sebuah model pemberdayaan anak muda. Anak muda belajar secara kritis fenomena keberagamaan yang secara teks dibahas dalam diskusi dan kajian-kajian. Serta mereka juga mencoba memikir ulang kembali keberagamaan yang sesuangguhnya, yakni toleran, tidak memaksakan kehendak, dan sesuai dengan potensi anak muda. Proses demikian dalam bahasa sederhana disebut sebagai keberagamaan yang moderat atau moderasi beragama.

\section{Kesimpulan}

Komunitas Santri Batang merupakan fenomena kegiatan beragama kaum muda di era millennial hari ini. Komunitas ini mempunyai tujuan moderasi beragama yang menyampaikan narasi perdamaian. Anak muda dalam komunitas ini berkumpul, berdiskusi, dan berkegiatan serta berproses dalam rangka membangun dirinya untuk meningkatkan kualitas diri agar lebih produktif dan bermanfaat. Narasi Islam Ramah yang mereka bangun terbukti mampu mengajak sesama kaum muda untuk bergerak bersama dalam memasyarakatkan moderasi beragama. Rangkaian kegiatan inilah yang merupakan model pemberdayaan moderasi anak muda berperspektif kritis yang menjadikan radikalisme, dan terorisme bisa diminimalisir di Indonesia salah satunya melalui Komunitas Santri Batang.

Tulisan ini memberikan gambaran bagi metode self etnografi, dan netnografi yang menjadi model alternatif pendekatan penelitian baik untuk meneliti masyarakat yang didalamnya peneliti menjadi bagian kelompok masyarakat tersebut dan juga selama masa pandemik berlangsung. Metode ini memungkinkan peneliti bisa meneliti dirinya, khususnya sebagai aktor pemberdayaan. Selain itu, peneliti diuntungkan dengan metode netnografi yang memudahkan 
peneliti mendapatkan data meskipun peneliti tidak bisa hadir secara fisik sebagai bagian dari masyarakat yang diteliti.

\section{Daftar Pustaka}

Afad, M. . (2018). Kalah Bondo Menang Konco: Strategi Gerakan Komunitas Anak Muda Ketjil bergerak Yogyakarta. Universitas Gadjah Mada. Alvara Research Center. (2020). » Indonesia Gen Z and Millenial Report 2020. https://alvara-strategic.com/indonesia-gen-z-and-millenialreport-2020/

Awan, I. (2016). Islamophobia on social media: A qualitative analysis of the facebook's walls of hate. International Journal of Cyber Criminology, 10(1), 1-20. https://doi.org/10.5281/zenodo.58517 Detik.com. (2015). Pelaku Bom Bali Berusia 20-25 Tahun. Detik.Com. https://news.detik.com/berita/d-454281/pelaku-bom-bali-berusia20-25-tahun

katadata.com. (2019). Aksi Teror Tewaskan Ribuan Jiwa Tiap Tahun / Databoks.

https://databoks.katadata.co.id/datapublish/2019/11/08/aksiteror-tewaskan-ribuan-jiwa-tiap-tahun\#

Kementrian Agama. (2019). Moderasi Beragama.

https://ntt.kemenag.go.id/file/file/InfoPenting/9af618d5bad1630e e838774153db6b4c.pdf

Kompas.com. (2009). Pelaku Bom Bunuh Diri Marriott Remaja 18 Tahun. https://tekno.kompas.com/read/2009/08/08/18180192/pelaku.bo m.bunuh.diri.marriott.remaja.18.tahun

Kumparannews. (2018). Dita Pelaku Bom Gereja Surabaya Dikenal Radikal Sejak SMA - kumparan.com.

https://kumparan.com/kumparannews/dita-pelaku-bom-gerejasurabaya-dikenal-radikal-sejak-sma

Muthohirin. (2015). Radikalisme Islam dan Pergerakannya di Media Sosial. Borang.Umy.Ac.Id. https://doi.org/10.18196/AIIJIS.2015

Naafs, S., \& White, B. (2012). Intermediate Generations: Reflections on Indonesian Youth Studies. Asia Pacific Journal of Anthropology, 13(1), 3-20. https://doi.org/10.1080/14442213.2012.645796

Noor, M. (2011). Pemberdayaan masyarakat.

http://103.98.176.9/index.php/civis/article/view/591

Republika. (2016). Indonesia Didorong Jadi Kiblat Bela Negara. 
https://republika.co.id/berita/ob15i1320/indonesia-didorong-jadikiblat-bela-negara

Ridwan, B., Syahputra, I., Tarigan, A., \& Siregar, F. (2019). Islam

Nusantara, ulemas, and social media: understanding the pros and cons of Islam Nusantara among ulemas of West Sumatera.

https://doi.org/https://doi.org/10.18326/IJIMS.V9I2.163-188

Seniman NU. (2019). Hari Santri Nasional 2019: Nilai Seorang Santri.

https://senimannu.com/hari-santri-nasional-2019/

Setyaningsih. (2019). Model Penguatan E-dakwah Di Era Disruptif Melalui

Standar Literasi Media Islam Online. TSAQAFAH, 15(1), 67-82.

https://doi.org/https://doi.org/10.21111/tsaqafah.v15i1.2947

Soetomo. (2006). Strategi-strategi pembangunan masyarakat.

https://books.google.co.id/books/about/Strategi_strategi_pembang unan_masyarakat.html?id=KEKdMgAACAAJ\&redir_esc $=y$

Statistik, B. P. (2018). Badan Pusat Statistik Kabupaten Batang.

https://batangkab.bps.go.id/dynamictable/2019/01/04/149/jumla

h-penduduk-menurut-kelompok-umur-dan-jenis-kelamin-2018.html

Tribunnews.com. (2019). Kepribadian Pelaku Bom Bunuh Diri di Pospam

Kartasura Berubah Sejak Lulus SMK di Solo.

https://www.tribunnews.com/nasional/2019/06/04/kepribadianpelaku-bom-bunuh-diri-di-pospam-kartasura-berubah-sejak-lulussmk-di-solo

Weng Hew, W. (2018). Print. Taylor \& Francis, 46(134), 61-79.

https://doi.org/10.1080/13639811.2018.1416757

Wulandari, P., Saraswati, D., \& Putra, S. (2017). Membangun Indonesia:

pemberdayaan pemuda berwawasan Pancasila.

https://books.google.com/books?hl=id\&lr=\&id=J8hVDwAAQBAJ\&oi

=fnd \&pg=PA3\&dq=pemberdayaan+pemuda\&ots=SVXxDVJQdB\&sig= dcXBwWQ6aPgFxiCuEiRIXuQD_BA

Zubaedi, M. (2016). Pengembangan masyarakat: wacana dan praktik.

https://books.google.co.id/books/about/Pengembangan_Masyaraka

t_Wacana_dan_Prakt.html?id=L8u2DwAAQBAJ\&redir_esc=y 